\title{
Visitors and Their Agendas in Myanmar: George Orwell (Author), Emma Larkin (Journalist), Hillary Clinton (Politician) and me (Social Researcher)
}

\author{
Dr. Claudia Bell* \\ Department of Sociology, University of Auckland, New Zealand \\ *Corresponding Author \\ Dr. Claudia Bell
}

\section{Article History}

Received: 28.01 .2020

Accepted: 04.02 .2020

Published: 15.02.2020

\begin{abstract}
Four diverse travellers are considered for their roles as agenda driven visitors, whilst also tourists. Central to their mission: finding ways to deal with the ruling regime in Burma / Myanmar, which could stymie their own projects, with dire consequences. Their commonality is that all were in Burma / Myanmar not despite the politics, but because of them. Each one of them upholds resistance to the oppressive regime. Yet all know to remain aware of the sensitivity of stating their responses to the dominant forces. Whilst in Myanmar, they must act, speak and write within safe parameters of engagement. That hyper-awareness places them in contrast with the everyday 'innocent' tourist.
\end{abstract}

Keywords: Myanmar, Burma, tourism, politics, democracy, military junta, Orwell, Clinton.

\section{INTRODUCTION}

Visitors to Myanmar have historically journeyed with various agendas. The context: a nation governed by a famously oppressive regime. In a country currently eagerly opening itself to international tourists, my commentary here is on four different travellers and their experiences. Inevitably, as foreigners in this space, all were also tourists.

The first, George Orwell, was part of the imperial administration ruling Burma during his time as a military policeman in the 1920s. His retrospective self-conscious reflections on the impacts of colonialism were examined in Burmese Days, first published in 1934 [1].

Nearly 70 years later, in 2002 journalist Emma Larkin retraced his journey, documented in Finding George Orwell in Burma. At a time when foreign writers and journalists were denied entry to Burma, she posed as a tourist [2]. Larkin is both anxious and courageous: she is enormously sensitive to the possible penalties for being seen to be taking too much interest in the brutal activities of the ruling regime.

U. S. Secretary of State Hillary Clinton visited Aung San Suu Kyi in Rangoon (now Yangon) in 2002. The formal schedule was to talk about the prospect of democratic reform in that authoritarian country. Like any dignitary on an official visit, Clinton was also taken to marvel at key tourist attractions.

My own visits in 2018 and 2019 were as an academic researcher from New Zealand, investigating grassroots development projects established by foreign residents. I was also a tourist, especially since the projects I visited were dependant on income from international visitors.

The key commonality of these visitors is that all were in Burma / Myanmar not despite the (often alarming) politics, but because of them. Each of these people affirms resistance to the oppressive regime. Yet despite their proactivity, all act with awareness of the sensitivity of asking or looking too closely at the dominant forces. They consciously seek, and act within, the safe parameters of engagement. Their hyper-awareness places them in contrast with the everyday 'innocent' tourist.

Copyright @ 2020: This is an open-access article distributed under the terms of the Creative Commons Attribution license which permits unrestricted use, distribution, and reproduction in any medium for non commercial use (NonCommercial, or CC-BY-NC) provided the original author and source are credited. 
Note: In 1989 the ruling military junta changed the name Burma to Myanmar. The main city Rangoon became Yangon. In 2005 a new capital city was created, Naypyitaw.

\section{THE FOUR VISITORS \\ George Orwell, Political Novelist}

In 1934 George Orwell's book Burmese Days was published. It is a novel based on his time as Eric Arthur Blair, serving with the Indian Imperial Police for five years in the 1920s.

The novel is set in the period when Burma was ruled by British colonialists in Delhi, as part of India. The dominance by pukka sahib (European white men) gives the main protagonist, a 35 year old teak merchant, status greater than that of local professionals. Set in a remote, fictional town, Kyauktada, the main plot involves the everyday lives of the British settlers. It is a tale of corruption in the local community, with a local magistrate determined to destroy an Indian doctor. Surely the intervention of the powerful white foreigner can save the situation? This was the basis of British colonialism itself, wasn't it? Orwell, ambivalent about imperial domination and army life, left Burma in 1927, after five years service. He focussed on his writing, reinventing himself as George Orwell in 1933. It is believed that his experiences in Burma inspired his later novels, Animal Farm (1945) and 1984 (1949) [4], [5]. As a preamble to his short story A Hanging (1931) Orwell wrote, 'imperialism was an evil thing and the sooner I chucked up my job and got out of it the better. Theoretically - and secretly, of course - I was all for the Burmese and all against their oppressors, the British. As for the job I was doing, I hated it more bitterly than I can perhaps make clear. In a job like that you see the dirty work of Empire at close quarters' [3].

\section{Emma Larkin, Journalist}

In 2002 American journalist Emma Larkin spent a year tracing the footsteps of Orwell. Finding George Orwell in Burma was published in 2002. She had previously visited in 1995, amazed that the 'postcard-perfect scenes of bustling markets, glittering pagodas an faded British hill stations...(concealed) one of worst records of human rights abuse in the world...the oppression of an entire nation of some 50 million people..(was) completely hidden from view' [2]. As for any tourist, the 'exotic veil' shrouded what lay beneath [6]. For present day visitors, history is told through pretty pagodas; narratives of vicious events are hidden.

Larkin's extraordinary political travelogue engages heavily with the context of the military dictatorship that rules the country. The story of her journey through early $21^{\text {st }}$-century Myanmar is a way of recounting conditions as one of the world's most repressive and insular dictatorships. At every step she is aware of how her journey might be (mis)interpreted by the current regime, the military junta. The persecution of journalists to Myanmar was forefront in her mind. This persecution is ongoing, with Pulitzer Prize winning Reuters reporters Wa Lone and Kyaw Soe Oo amongst those incarcerated in 2017. (Both were released after 500 days). For her books about Burma Emma Larkin uses a pseudonym: her 'strategic uses of anonymity (and) concealment... as a political historian of the complex national transformation from colonial subjugation (as Burma) under the British into the modern totalitarian state of Myanmar' [7]. Her travel biography of Orwell exposes an illicit literary culture, which 'sustains its own underground, biased "reporting" of the abuses of Myanmar's military regime in the early years of the twenty-first century' [7]. That dominance shaped both Orwell's legacy, and how Emma Larkin must undertake her own clandestine research. Her work has been escribed as 'a deeply scary history lesson on the fate of pre and post-colonial Myanmar' [8].

\section{Hillary Clinton, U. S. Secretary of State}

In 2011 US Secretary of State Hillary Clinton visited Yangon to meet Aung San Suu Kyi, winner of the 1991 Nobel Peace prize for her passionate efforts in non-violent struggle for democracy and human rights. She is daughter of General Aung San, commonly referred to as 'hero father of the nation'. 'My father died when I was too young to remember him', she wrote in her 1991 book Freedom from Fear [9]. 'When I honour him, I honour all those who stand for political integrity in Burma' [9]. He led the Burmese struggle for independence from Britain and Japan. In modern Myanmar, Aung San Suu Kyi rose to prominence in the 1988 Uprisings. She became General Secretary of the new National League for Democracy (NLD), set up to oppose the ruling military junta. Her overwhelming 1990 election win was nullified, as the military refused to concede power. She lived mostly under house arrest in Yangon from $1989-$ 2010. In 2010, whilst detained, her party could not participate in the elections, resulting in the claiming of decisive victory for the military-backed Union Solidarity and Development Party. That electoral process was widely decried as 'a charade' [2].

Clinton's goal: to assist with early steps in democratic reforms in Burma, against - or alongside - the ongoing influence of the brutal military regime. Clinton visited Aung San Suu Kyi in the chief U. S. diplomat's home; 'The Lady' had been released from house arrest. Clinton also met President Thein Sein, former leader of the military junta, credited with much of the democratic progress to date [10, 11]. Clinton's account of her visit. 'Burma: The Lady and the Generals' is Chapter 6 in Hard Choices 2014. This is a memoir of her relationships with many global states during her 
time as U. S. Attorney General. In that chapter she refers to the 'chance to help Burma move from dictatorship to democracy' [10]. Her comments were endorsement of Aung San Suu Kyi, at that time reaffirming her recognition by the world. Clinton's prognosis for Burma's political future could be described as determinedly optimistic.

Since that visit, events have continued to unfold. In the 2012 and 2015 elections Aung San Suu Kyi's party won by landslides. Banned from becoming president, she assumed the newly created role of State Counsellor, a role akin to a Prime Minister or a head of government. By 2017, commentators were declaring that the democratic process in Myanmar was coming to a standstill [12]. As I write (January 2020), in apparent contradiction to her earlier ideologies, Aung San Suu Kyi has been appearing in the International Court of justice (ICJ) in the Hague. She is defending herself against her inaction in response to the genocide of the Muslim Rohingya people in the northern Rakhine state [13].

\section{The Social Justice Researcher}

My own recent visits there have been as a social researcher investigating 'social good' development enterprises. In 2018 and 2019 I spent time at various social justice ventures operated by foreign residents. None of these were officially recognised NGOs. All were operations created and operated by altruistic individuals [14], working closely with local people in direct response to needs. The projects are wholly independent, with no fiscal or other support from governmental agencies or from international aid agencies. The operators set up the schemes using their own resources, sometimes adding donations from personal contacts, then advance their enterprise to be financially self-sustaining. Most form small business partnerships with local people who work with them.

These people are 'drivers of cross-border transfers of knowledge and skills' [15]. It is not just the hands-on skills that are imparted; they also teach local people how to manage such enterprises as a continuing successful business. The projects included handcraft and artisan initiatives, often using recycled materials eg furniture restoration, or merchandise created from old bicycle tyres or papier mache. There were also various types of food production, including bee keeping. Training restaurants upskill worker for the lucrative, sophisticated dining niche; eco-tours guaranteed clients a chance to see rare sights, through engaging with local guides. For the social entrepreneurs who founded and operated these enterprises, their schema is responsible, grassroots development, with an unwavering social justice agenda [14]. All profits are poured back into the project, and hence into the community. As a social researcher, my schedule was to explore the rationales and impacts of these interventions, as a strand of development for tourism. Most projects were aimed at international tourists as customers or consumers.

The entrepreneurs running these small businesses have no power to deal with significant political issues. Rather, their undertakings concentrate on pro-social values [16], providing practical assistance to underprivileged local people, where they can. Tourists arrive with money to spend; these enterprises deliver unique experiences and desirable merchandise. The income is direct support to deprived local people. Their projects are implicit critique of the government failure to successfully address poverty [17]. The successes might seem small scale; but poverty alleviation an training for employment is hugely significant to the lives of those directly empowered [14].

Inevitably, the foreign social researcher is also a tourist. Like Clinton and Larkin a visit to Myanmar involves visits to local attractions. The social justice sites also relied on tourists as customers. Many tourists consciously seek such operations, the notion of 'fair trade' driving their shopping and experiences. In this context, researcher praxis closely resembles tourist praxis. Like any visitor, I had located the enterprises via websites, travel blogs, and once in Myanmar, in the field. I also paid for goods and services from each business, just as tourists do. Politicians, journalists and researchers outside their own countries inevitably combine tourism with their key agenda.

\section{DisCUSSION}

In the case of all of these individuals, the visit was not despite the politics at the time, but because of them. Orwell was part of the colonising process. Larkin, through trailing Orwell, wrote an expose of the current regime. She noted the 'uncanny twist' that Orwell's three major novels: Burmese Days, Animal Farm (1945), and Nineteen Eighty Four (1949) 'effectively tell the story of Burma's recent history'. After independence on 1948, Burma was sealed off from the outside world, the events resonant in Animal Farm, a tale of a socialist revolution gone wrong. Atrocious elements of 'one of the world's most brutal and tenacious dictatorships' are echoed in the chilling dystopia in Nineteen Eighty Four [2].

Clinton was on a mission to help achieve democracy in Myanmar, in the face of the presiding administration. This researcher was finding foreign individuals in Myanmar who are making grassroots interventions to address consequences for the poorer inhabitants, victims of the fiscal failures of government. The connection between them all was that, in their diverse ways, all were reacting against and /or documenting the impacts of the oppressive regime. For myself, the most recent visitor, this took place in the setting of global advertising of the bright face of Myanmar as a new 
tourist destination: expedia, lonely planet, tripadvisor, intrepidtravel et al., The Myanmar government website invites tourist to 'enchanting' Myanmar [18]. Meanwhile the New Zealand government travel website recommends that tourists 'Exercise increased caution in Myanmar, including in the Mandalay region due to the readily changeable political situation and regular civil unrest' [19].

All of these visitors were in Burma / Myanmar to address and redress the fallout from current politics. They could see though the propaganda of government policy that is the norm in Myanmar [12]. Each was proactively resistant to the ideologies, values, actions and obscuration of the repressive regime.

That proactivity requires a constant high level of consciousness of caution when commenting too casually to strangers about Myanmar's current political situation. Larkin often describes situations where she is treated with suspicion by local authorities: why is she travelling to such remote regions, far from the usual tourist trail? She is ever vigilant of the need to accede to safe boundaries. The officials distrust Larkin. She distrusts them. She knows that later, safely away form Myanmar and under a pseudonym, she will be writing about what she saw and heard. Meanwhile, all media in Myanmar is controlled by strict censorship; 'these methods at reality-control are kept firmly in place by the invisible though ever present, threat of torture an imprisonment' [20]. Though such censorship as officially dropped in 2012, 'to avoid potential repercussions journalist continue to practice self censorship; penalises can still be applied to any news reporting facing objection by the regime. There is scant faith in state run newspapers after decades of top down control of the entire media environment' [21]. Hence Larkin's need for extreme caution, seeking safety by posing as an ingenuous tourist.

This knowledge also requires caution in the researcher. Universities employing social scientists are obliged to play it very safe. The essential mantra of 'do no harm' to participants is always born in mind. The regime may not see any benefit in a foreign researcher asking questions. In this situation, the role of the critical tourism scholar is set quietly to one side; social, political and cultural critique are more than unwelcome. Far better to behave like Larkin, and perform an obviously tourist role, than a researcher role [14].

Tourists do not have to deal with this dilemma. Myanmar opened for tourism in 2013. Global news coverage of the Rohinga crisis caused international abhorrence [13]. Nonetheless, visitor numbers are growing rapidly, with over 3 million tourists reported in 2018 [22]. Once a visa is granted and the visitor is admitted into Myanmar, it is easy to travel about in a privileged bubble, oblivious to conditions of the local people; or perceiving them (as many travel blogs illustrate) as novel local colour. The average stay is 11 nights. The diverse attractions require full travel days, for example for a night or two in Bagan, the temple landscape; and to Lake Inle, the highlights for most visitors. The 'exotic veil' [6] is enchanting: visitors enjoy a liminal world of glorious temples, colourful monks, fascinating markets, docile service staff, and delicious, exotic food. My appraisal (today, while writing this paper) of 20 random blogs about travel in Myanmar reveals repeated references to these features.

Recent history of Myanmar is politically contentious; controversial events are not included in story telling for tourists. On the ground, the tour guides' narratives draw from the distant past, when temples and Buddhas were built. Brutal history is displaced by sanitised displays of cultural heritage, which draw an exotic curtain, fashioned to enchant and deflect tourist attention from atrocious historical events and legacies Hosting tourists involves processes of staging and performing a form of authenticity to charm guests, persuading them that this is the real country, and this it genuine fascinating culture. Like the tour guides investigated in Oman, they must 'obscure a violent history, a police state, censorship, corruption an social inequality, by weaving a fragrant veil of Orientalist spells around the visitors' [6].

The tour guides are complicit in these omissions, as they show off picturesque ongoing traditions, such as the floating gardens, floating villages and traditional fishermen on Lake Inle, which appear locked in time. There is no overt comment about tourists being people who are wealthy enough to come and gaze upon poverty; or why such poverty persists. This control of historic narratives highlights the contradictions between academic and popular story-telling about place; and between the agenda-driven visitors (my examples above) and the casual tourist. The sheer beauty and 'exotic' nature of Myanmar are seductive distractions from anything objectionable. These are not 'value free expressions of place identity, but, to varying degrees, are influenced, managed and sustained' [6] by a need to not rock any political boats.

Myanmar lines up nicely with outsider notions of Orientalism: exotic, fascinating, ancient. For visitors the very low cost of living is also attractive, alongside the sense of privilege the tourist enjoys, vis a vis local people. Tourist or 'expatriate national identities can still be grounded in historical notions of racial and cultural superiority versus the local other' [15]: a residual sense of entitlement as temporary recolonises sits comfortably with many western tourists [14]. 
This reinforcement of Myanmar as oriental 'other' is proving commercially successful [23]. Evidence rests in recent statistics on Myanmar's income from tourists [24]. For a tourist, part of being on holiday is to escape the quotidian, including politics. A tourist destination is something of an imaginary world; a fantastical fairyland space happily remembered and imagined later, at home, during the return to mundane everyday life.

The world has been watching as Myanmar's reforms have soared since 2010. In 2012 U. S. President Barak Obama visited, accompanied by Hillary Clinton. Clinton described the rapid progress evident in Yangon. At Obama's request they make an unscheduled stop at the huge golden Shwedagon Temple. They strolled through the grounds 'as close to being a couple of regular tourists as a President and Secretary of State can get' [25]. They paused their official programme for a little interlude of touristic pleasure.

\section{CONCLUSION}

In 2018 over 3 million tourists visit Myanmar. Those registered arrivals included people who went there, not just to take in the glorious sights, but for some particular non-tourist agenda. This required them to find ways to deftly stay under the radar and sidestep the regime, in order to fulfil their own mission.

George Orwell complied with his duties in Burma, then, disillusioned, abandoned them. Hillary Clinton's position as U. S. Secretary of State demanded that she apply rigorous diplomacy when dealing with any appalling global situation. Larkin's book about tracking Orwell is a sobering illustration of the need for obedience for fear of repercussions if her real agenda is exposed. My own approach followed hers: take great care, don't cause trouble, don't risk getting arrested, don't endanger research participants [24]. Best strategy: present oneself as just another naïve tourist. All knew to judiciously navigate and negotiate the fragile borders of transgression, for their projects to reach successful completion.

For each of these four visitors, all were driven to gather information, even if this required apparent complicity with the ruling regime, whilst in Burma / Myanmar. For each of these four visitors, their goal was to transmit information, and make their insights available, once safely out of Burma /Myanmar. From Orwell's appointment in the 1920 s, to the time of my own visits almost a century later, Myanmar's progress towards democracy has provided agendadriven travellers with multivariate, but dedicate, engagement.

\section{REFERENCES}

1. Orwell, G. (2009). Burmese Days with Introduction by E. Larkin. Penguin Classics, UK.

2. Larkin, E. (2011). Finding George Orwell in Burma. UK: Penguin Books.

3. Malreddy, P. K. (2019). Imperialist shame and indigenous guilt: George Orwell's writings on Burma. European Journal of English Studies, 23(2):311-325.

4. Moore, D. (2018). George Orwell's Legacy. Metaphor No. 3, 22-24.

5. Larkin, E. (2009. 'Introduction to Burmese Days' p v - xiii. George Orwell Burmese Days. UK; Penguin Classics.

6. Causevic, S., \& Neal, M. (2019). The exotic veil: Managing tourist perceptions of national history and statehood in Oman. Tourism Management, 17:504-517.

7. 9 Wilson, C. P. (2014). 'Finding Emma Larkin' Literary Journalism Studies; 6(2):48-72.

8. Mitchell, C. (2005). Emma Larkin: Secret Histories: Finding George Orwell in A Burmese Tea Shop. Book Review, Spike Magazine, January 2005.

9. Aung San Suu Kyi. (1991). Freedom from Fear. England; Penguin Books; page 3.

10. Clinton, H. (2014). Hard Choices. New York: Simon and Schuster.

11. Burrett, T. (2017). Mixed Signals: Democratization and the Myanmar Media. Politics and Governance. 5(2):41-58.

12. Roewer, R. (2017). Myanmar's National league for Democracy at a Crossroads. IGA Focus, Asia. No 01, April.

13. Choudhury, A., \& Helduk, F. (2019). Aung San Suu Kyi at the International Court of Justice. Stiftung Wissenschaft and Politic (SWP): Germany.

14. Bell, C. (2019). The Tourist / Researcher Nexus: investigating Social Justice Projects in Cambodia, Myanmar and Laos. Advances in Social Sciences and Culture, 1(2).

15. Kunz, S. (2016). Mobilities: Locating the Expatriate in Migration Scholarship. Geography Compass, $10(3): 102$.

16. Borquist, B. R., \& de Bruin, A. (2019). Values and women-led social entrepreneurship. International Journal of Gender and Entrepreneurship. 11(2):146-165.

17. Saebi, T., Foss, N. J., \& Linder, S. (2019). Social entrepreneurship research: Past achievements and future promises. Journal of Management, 45(1), 70-95.

18. https://tourism.gov.mm/ 
19. https://www.safetravel.govt.nz/myanmar

20. Palmer, L. J., Buxbaum, S. G., Larkin, E. K., Patel, S. R., Elston, R. C., Tishler, P. V., \& Redline, S. (2004). Whole genome scan for obstructive sleep apnea and obesity in African-American families. American journal of respiratory and critical care medicine, 169(12), 1314-1321.

21. Dolan, T., \& Gray, S. (2014). Media and Conflict in Myanmar. Opportunities for Media to Advance Peace. United States Institute of Peace. https://www.files.ethz.ch/isn/175602/PW92.pdf; page 16.

22. Myanmar Times, January $10^{\text {th }}, 2020$.

23. Kerrigan, F., Shivanandan, J., \& Hede, A. M. (2012). Nation branding: a critical appraisal of incredible India. Journal of Macromarketing, 32(3), 319-327.

24. Ministry of Hotels and Tourism. Myanmar Tourism Statistics 2018 https://tourism.gov.mm/statistics/

25. Clinton, H. R. (2004). Now can we talk about health care. The New York Times Magazine, 26. 